\title{
Quality of Life Indicators and Their Impact on Social Work Practice
}

\author{
Charla J. Lautar, PhD \\ Southern Illinois University, Carbondale, IL USA
}




\section{Egyptian Journal of Social Work (EJSW) http://ejsw.journals.ekb.eg \\ Print ISSN: 2356-9204 Online ISSN: 2356-9212 Vol 1, Issue 1, June 2015}

\section{Abstract}

Currently, there is no broad agreement on what constitutes quality of life. However, there are various characterizations of this concept based on the perceptions of the individual. In social work practice, quality of life indicators are helpful for assessing social, economic, and environmental conditions that affect the client's well being. This paper will discuss various models used for evaluating quality of life. Awareness of quality of life indicators - such as education, employment, environment, health, income, shelter, and safety - will prepare the social worker to meet the challenges encountered daily by clients. Recommendations and implications for creating a better or higher quality of life, as well as considering the client's value system, will be addressed.

\section{Kay Wards: Quality of Life, Indicators, Social Work Practice Introduction}

Quality of life (QL) encompasses both psychosocial and physical aspects of one's life. The concept of QL means different things to different people and what is important or of interest to an individual differs from that for another individual. Although health is used to define QL in the medical context, QL can also be defined in terms of indicators or attributes such as income, work, and social support. Some authors view QL as an answer to the question: "How good is your life for you?" (Raphael, Brown, Renwick, \& Rootman, 1994). Quality of Life is not constant and changes over time with experience and coping mechanisms (Allison, Locker, \& Feine,1997). Population groups may also have a change in quality of life based on improvement or decline of services.

Quality of life is very relevant to the role of the social worker as an advocate and facilitator that aims to improve the lives of clients and the community in which they reside. Social, cultural, and economic characteristics inter-relate and should be considered when judging what one is able to act upon to improve or sustain quality of life. This paper examines a few of the questionnaires and indicators that are used to evaluate quality of life, and provides a selected literature review. Also, the role that social workers can play in using these questionnaires and identifying indictors will be discussed.

\section{Measuring Quality of Life}




\section{Egyptian Journal of Social Work (EJSW) http://ejsw.journals.ekb.eg \\ Print ISSN: 2356-9204 Online ISSN: 2356-9212 Vol 1, Issue 1, June 2015}

The idea behind constructing scales to measure QL is to quantify the individual's perception of his/her QL such that it can be compared and followed over time. This is achieved by ascribing numerical values to various elements of QL. Many of the tools used to measure QL depend on self-reported responses to a questionnaire which lists a series of indicators that are used to assess the individual's QL. Results obtained from QL measurements are used for collecting data for research purposes, such as epidemiological studies, to set public policy, and to prioritize funding and resources (Rabkin, Wagner, \& Griffin, 2000). For the individual, QL measurements are used to determine if a specific intervention, such as treatment, policy, or program, is needed.

Wallace and Pichler (2008) restrict the use of the term wellbeing for measuring individual indicators such as work, housing and social relationships. Culture seems to play a role in one's perception of quality of life. Schalock et al (2005) investigated 24 indicators (eight domains with three indicators per domain). The study involved five geographic groups and four world regions, as well as three respondent groups: consumers, parents, and professionals. This study suggested that there were significant differences among respondents and geographic groups in rating importance and use of services.

Quality of life is often used for measuring society as a whole and uses objective indicators. For example, the United Nations' Human Development Index (HDI) assesses countries according to economical, health, and educational factors and includes data for life expectancy, poverty, gender and human rights. Likewise, CalvertHenderson (2008) identified twelve factors that influence QL and provides a means to assess countries. These indicators are in the following areas: education, employment, energy, environment, human rights, income, infrastructure, national security, public safety, recreation/self-improvement, and shelter. An individual country may have an index, which is measured at specific time intervals to determine the QL in that country under various circumstances.

Another tool used to assess quality of life is the Quality of Life Interview. This instrument has a long (original) version that would take 45 minutes to administer and a short (revised) version which would take about 16 minutes. Items cover feelings of satisfaction, functional status and access to resources for eight domains of 1) living 
situation, 2) family relations, 3) social relations, 4) leisure, 5) finances, 6) work and school, 7) legal and safety issues, and 8) health. Using a 1 to 7 Likert scale, respondents would state if they feel terrible (1) or delighted (7). This scale was developed to help in planning and evaluating services and treatment outcomes. It can be administered with very little training and the primary purpose is to assess quality of life in those with chronic mental illness (Lehman, 1988).

\section{Life Satisfaction and Happiness}

A number of investigators identify the concept of QL with life satisfaction or happiness. Veenhoven (1991) has defined life satisfaction "as the degree to which an individual judges the overall quality of his life - as a whole - favorably" (p. 10). Additionally, Satisfaction of Life surveys are used to evaluate the psychological components of QL such as happiness. For example, the Diener's Satisfaction with Life Scale utilizes five statements on a seven-point Likert scale. Individuals are asked to rate the following: 1) In most ways my life is close to my ideal; 2) The conditions of my life are excellent; 3) I am satisfied with my life; 4) So far I have gotten the important things I want in life; and, 5) If I could live my life over, I would change almost nothing. A total score is given; however, it has been argued that the limitation of this scale is the lack of individualizing the variables (Slocum-Gori, Zumbo, Michalos, \& Diener, 2008). Thus, social workers should be cautioned when this particular scale is used to describe groups, and be cognizant of its limited value working with individual clients.

Another example of a satisfaction with life survey is the Quality of Life Enjoyment and Satisfaction Questionnaire (QLES-Q). This questionnaire can be used for screening, assessment, and intervention, especially for mood disorders. It consists of 60 Likertscale items and examines physical health, subjective feelings, leisure time activities, social relationships and general activities. When applicable, other evaluated items also include work, school and household activities. There is also a shortened form consisting of 16 items. The short survey would be very useful to social workers as it is self-administered, takes 15 minutes, and is calculated by percentage of the maximum score (Endicott, 1993; Mullen, 2004). 


\section{Egyptian Journal of Social Work (EJSW) http://ejsw.journals.ekb.eg \\ Print ISSN: 2356-9204 Online ISSN: 2356-9212 Vol 1, Issue 1, June 2015}

One's perception of happiness may also be used synomously with satisfaction. Although happiness is correlated with quality of life, the relationship is not causal. In a review of the literature, Argyle and Martin (1991) found that social interaction, job satisfaction, extraversion, and leisure/relaxing activities are correlated with happiness. Similar findings were found when comparing American teenagers with Italian teenagers; both groups had high levels of happiness when involved with sports/games, socializing, eating, and art/hobbies (Csikszentmihalyi \& Wong, 1991, p. 203) and highest with structured leisure activities (p. 210).

Wallace and Pichler (2008) addressed the question: Are people who participate in civil society happier individuals? Studying eighteen European counties, they examined the participation and level of involvement (none, member, more than a member) in civil society such as playing sports, volunteering, and membership in associations, trade unions, religious organizations (i.e., mosques, churches) and other activities. Their results suggest that participation depended on factors such as age, gender, social class, education and residence (urban/rural). These authors found that satisfaction with life depended not only on civil society participation but also on the specific association that one participated in and the country in which one resided. Furthermore, these authors speculated that non-participation could be attributed to historical conditions of the country or, on an individual level, when people are more concerned with their basic needs than on broader issues in society. However, it was also suggested by this study that those who participate in civil society also become more satisfied with society in general. These factors should be considered as social workers facilitate individuals and groups to become agents of change within their own communities (Rothman, 2001) and empower their clients not only for individual situations but for the community as a whole.

\section{Health and Quality of Life}

Most often, QL is associated with health. The World Health Organization (WHO) defines health as "state of complete physical, mental and social well-being and not merely the absence of disease or infirmity" (p. 100). However, this may be confounded because an individual may feel that a health problem is not serious based on how it impacts daily life or performance of normal tasks, and thus does not 
seek care. Locker (1997) states the definition of health as "an individual's subjective experience of his/her functional, social and psychological well being" (p. 15). Furthermore, the patient's assessment of QL, which could be subjective, may be different from the opinion of the health care professional, which could be objective, or the perception of a caretaker. Thus the term "health-related quality of life" has emerged, and relates health status to symptom status, functional status (physical, social, psychological), perceptions, social opportunities, and impairments in role-related jobs, family and other commitments (Gill \& Feinstein, 1994; Stewart et al., 1989).

In the health area, QL measurements are used to evaluate conditions ranging from mental to dental, from disabilities to cancer, from back pain to chronic pain, and cross population groups (e.g., age, gender, social class, ethnicity). Moreover, one does not only evaluate the physical or biomedical component of disease, but also the social and emotional aspects (personal, cultural, environmental, political, psycho-social influences) of either presence or absence of disease (Engel, 1977; Wilson \& Cleary, 1995). Thus quality of life in relationship to health involves clinical and non-clinical indicators and characteristics of both the individual and the environment.

One needs to shift thinking from a medical model of treating disease to a socio-environmental model of what health is and how we attain it (Nettleton, 1995). For example, individuals with chronic disabilities may rate their QL higher in comparison to healthy individuals (Allison, Locker, \& Fiene, 1997). However, a study of those with disabilities suggests that these individuals need twice the income level than those without disabilities to attain the same level of economic satisfaction (Rosano, Mancini, \& Solipaca, 2008). This illustrates that disabled individuals need more resources to feel the same degree of satisfaction as those without disabilities. Although genes, family history, and access to care do play a major role in health, it is important to take a closer look at job loss, isolation, bereavement, job satisfaction, rewarding family life, personal fulfillment, and socioeconomic factors (Gunderman, 1995, p. 682).

Another example of measuring QL and health is the Sickness Impact Profile (SIP). This index is used for: 1) assessing health of populations, 2) evaluating medical care programs, 3) evaluating treatment programs, 4) planning and program development, and 5) 
assessing individual patient's status and response to health care (Bergner et al., 1981). It consists of both physical and psychosocial domains, and is composed of 14 categories: social interaction, ambulation, sleep and rest, taking nutrition, usual daily work, household management, mobility/confinement, movement of the body, communications, pastimes/recreation, intellectual function, family interactions, emotions/sensations, personal hygiene (Gilson et al., 1975). Respondents indicate either yes or no to a statement. The SIP index has been revised from 312 statements to 234 statements. A shortened form of the SIP is the Roland Scale, which consists of only 24 items.

\section{Implications for Social Work Practice}

The social worker, in the function as an advocate, can be a key player in promoting the quality of life for both the individual client and society. Through supporting and empowering, the social worker can take actions to improve QL by promoting positive attitudes to life. Social workers can use QL scales for clients seeking consultation regarding career change, marital problems, financial stress, or chronic illness. Assessment of QL can give an idea about the depth of the problem and follow-up assessment can help determine progress.

Social workers can guide their clients to achieve a balance between the factors that influence present conditions for happiness and well-being (e.g., social relationships, including family interactions) and the factors that may improve conditions in their future and long-term goals (e.g., housing, work, and education). The latter factors may jeopardize current attainment for happiness and well-being.

Social workers are cautioned that quality of life indicators look at the "here and now" and do not take into consideration social conditions such as on-going wars, natural disasters, and resource reductions. These characteristics of society are often over-looked but are becoming increasingly important in our daily lives. Likewise, there is no QL instrument to measure ethnic differences by utilizing culturally relevant indicators (Daniel et al., 2008). Social workers should be aware of the need for cultural competency when assisting their clients (Lautar, 2008). Furthermore, social workers can expand their roles by developing new tools that are specific for the population 
groups with whom they are working or investigating new indicators that would be more precise to the culture of their individual clients.

It is helpful for the social worker to have a fast and effective way to determine how satisfied the client is with the quality of his/her life. A questionnaire could be the starting point for a discussion of what aspects of life could be changed, what is needed to make that change, how the social worker could facilitate that change, and how this information could be used to compare with past and future information for both the individual client and the population group studied. The simple yes/no answer would be the quickest for the social worker to tabulate and would take less time for the client to provide. However, more information would be available if the client was also able to write down comments. This would provide more information for discussion. The following Appendix illustrates common elements in quality of life questionnaires and indictors that could be used to evaluate quality of life and to stimulate discussion.

\section{APPENDIX}

\section{Sample Questions to Determine Quality of Life}

1. Do you feel that you have enough time for your spouse? Yes No

2. Do you feel that you have enough time for your family? Yes No

3. Do you feel that you spend enough time with your friends?

$$
\text { Yes No }
$$

4. Do you enjoy your work? Yes No

5. Do you feel that your job is financially rewarding? Yes No

6. Do you have hobbies or regular leisure activities? Yes No

7. Do you play sports and/or exercise regularly? Yes No

8. Do you belong to any association, volunteer for any activities, participate in any organization?

Yes No

9. Does your physical health allow you to participate in daily activities? Yes No

10. Does your mental health allow you to participate in daily activities?

$$
\text { Yes No }
$$

Positive values of one (1) can be assigned to "yes" answers and Zero (0) values to "no" answers to calculate a total score. 


\section{Egyptian Journal of Social Work (EJSW) http://ejsw.journals.ekb.eg \\ Print ISSN: 2356-9204 Online ISSN: 2356-9212 Vol 1, Issue 1, June 2015}

A score of ten (10) would indicate a satisfied or good quality of life.

\section{References}

Allison, P. J., Locker, D., \& Feine, J. S. (1997). Quality of life: A dynamic construct. Social Science and Medicine, 45, 221-230.

Argyle, M, \& Martin, M. (1991). The psychological causes of happiness. In F. Strack, M, Argyle, \& N. Schwarz (Eds.), Subjective well-being: An interdisciplinary perspective (pp. 77-100). New York: Pergamon Press.

Bergner, M., Bobbit, B., Carter, W.B., \& Gilson, B. S. (1981). The Sickness Impact Profile: Development and final revision of a health status measure. Medical Care, 19, 787-805.

Gilson, B. S., Gilson, J. S., Bergner, M., Bobbitt, R.A., Kressel, S., Pollard, W.E., \& Vesselago, M. (1975). The Sickness Impact Profile: Development of an Outcome measure of health care. American Journal of Public Health, 65(12), 1304-1310.

Calvert-Henderson. (2008). Overview: Inside the Calvert-Henderson quality of life indicators. Accessed 10/9/2008

www.calvert-henderson.com.

Csikszentmihalyi, M., \& Wong, M. M-H. (1991). The situational and personal correlates of happiness: A cross-national comparison. In F. Strack, M. Argyle, \& N. Schwarz (Eds.), Subjective well-being: An interdisciplinary perspective (pp. 193- 212). New York: Pergamon Press.

Daniel, M., Cargo, M., Marks, E., Paquet, C., Simmons, D., Williams, M., Rowley, K., \& O'Dea, K. (2008). Rating health and social indicators for use with indigenous communities: A tool for balancing cultural and scientific utility. Social Indicators Research doi: 10.1007/s 11205-008-9420-7.

Endicott, J., et al. (1993). Quality of life enjoyment and satisfaction questionnaire: A new scale. Psychopharmacology Bulletin, 29, 321326.

Engel, G. (1977). The need for a new medical model: A Challenge for biomedicine. Science, 196, 129-136.

Gill, T. M., \& Feinstein, A. R. (1994). A critical appraisal of the quality of quality-of-life measurements. Journal of the American Medical Association, 272(8), 619- 626. 
Gunderman, R. B. (1995). Rethinking our basic concepts of health and disease. Academic Medicine, 70(8), 676-683.

Lautar, C.J. (2008). Integrating socioeconomic and cultural perspectives in medical social work practice. Proceedings of the $21^{\text {st }}$ International Scientific Conference of Social Work: Social Work and Human Welfare in a Changeable Community (pp. 233-263). Cairo, Egypt: Helwan University.

Lehman, A. F. (1988). A Quality of Life Interview for the chronically mentally ill. Evaluation and Program Planning, 11, 51-62.

Locker, D. (1997). Concepts of oral health, disease and the quality of life. In G. D. Slade (Ed.), Measuring oral health and quality of life (pp. 11-24). Chapel Hill, NC: $\quad$ University of North Carolina.

Mullen, J. (Ed). (2004). Manual of rating scales for the assessment of mood disorders. Wilmington, DE; AstraZeneca Pharmaceuticals LP.

Nettleton, S. (1995). The sociology of health and illness. Cambridge: Polity Press.

Rabkin, J., Wagner, G., \& Griffin, K.W. (2000). Quality of life measures. In A. J. Rush, et al. (Eds.), Handbook of psychiatric measures (pp. 135-150). Washington, DC: American Psychiatric Association.

Raphael, D., Brown, I., Renwick, R., \& Rootman, I. (1994). Quality of life theory and assessment: What are the implications for health promotion (Issues in Health Promotion series). Toronto, Ontario: University of Toronto, Center for Health Promotion.

Rosano, A., Mancini, F., \& Solipaca, A. (2008). Poverty in people with disabilities: Indicators from the capability approach. Social Indicators Research.

doi: 10.1007/s11205- 008-9337-1.

Rothman, J. (2001) Approaches to community intervention. In J. Rothman, J. L. Erich \& J. E. Tropman (Eds.), Strategies of community intervention. Itasca, IL: Peacock Publishers.

Schalock, R. L., Verdugo, M.A., Jenaro, C., Wang, M., Wehmeyer, M., Jianchen, X., \& Lachapelle, Y. (2005) Cross-cultural study of quality of life indicators. American Journal on Mental Retardation, 110(4), 298-311.

Slocum-Gori, S.L., Zumbo, B.D., Michalos, A. C., \& Diener, E. (2008). A note on the dimensionality of quality of life scales: An 
illustration with the Satisfaction with

Life Scale

(SWLS).

Social Indicators Research. doi: 10.1007/s11205-008-9303-y.

Stewart, A. L., Greenfield, S., Hays, R. D., Wells. K., Rogers, W. H., Berry, S. D., McGlynn, E. A., \& Ware, J. E. (1989). Functional status and well-being of patients with chronic conditions: Results from the Medical Outcomes Study.

Journal of the American Medical Association, 262(7), 907-913.

Veenhoven, R. (1991). Questions on happiness: Classical topics, modern answers, blind spots. In F. Strack, M. Argyle, \& N. Schwarz (Eds.), Subjective well-being: An interdisciplinary perspective (pp. 7-26). New York: Pergamon Press Wallace, C., \& Pichler, F. (2008). More participation, happier society? A comparative study of civil society and the quality of life. Social Indictors Research doi:10.1007/s11205-008-9305-9.

Wilson, I. B., \& Cleary, P. D. (1995). Linking clinical variables with health-related quality of life: A conceptual model of patient outcomes. Journal of the American Medical Association, 273, 59-65. World Health Organization. (1948). Preamble to the Constitution of the World Health Organization (Official Record, No. 2). New York: Author. 